\title{
Modulation of rat liver urea cycle and related ammonium metabolism by sex and cafeteria diet
}

Silvia Agnelli ${ }^{1}$, Sofía Arriarán ${ }^{1}$, Laia Oliva ${ }^{1}$, Xavier Remesar ${ }^{1,2,3}$, José-Antonio Fernández-López ${ }^{1.2 .3}$ and Marià Alemany ${ }^{1,2,3}$

${ }^{1}$ Department of Nutrition and Food Science, Faculty of Biology, University of Barcelona; Av. Diagonal 643; 08028 Barcelona, Spain

2Institute of Biomedicine, University of Barcelona; Av. Diagonal, 643; 08028 Barcelona, Spain

${ }^{3}$ CIBER-OBN Research Web, Barcelona, Spain

Author for correspondence:

Dr. Marià Alemany; University of Barcelona Faculty of Biology, Department of Nutrition and Food Science; Av. Diagonal 643; 08028 Barcelona, Spain; e-mail: malemany@ub.edu. 


\section{SUMMARY}

High-energy (hyperlipidic) cafeteria diets induce insulin resistance limiting glucose oxidation, and lower amino acid catabolism. Despite high amino-N intake, amino acids are preserved, lowering urea excretion. We analysed how energy partition induced by cafeteria diet affects liver ammonium handling and urea cycle. Female and male rats were fed control or cafeteria diets for 30 days. There was a remarkable constancy on enzyme activities and expressions of urea cycle and ammonium metabolism. The key enzymes controlling urea cycle: carbamoyl-P synthase 1 , arginino-succinate synthase and arginase expressions were decreased by diet (albeit more markedly in males), and their activities were correlated with the gene expressions. The effects observed, in ammonium handling enzyme activities and expressions behaved in a way similar to that of the urea cycle, showing a generalized downregulation of liver amino acid catabolism. This process was affected by sex. The different strategies of amino- $\mathrm{N}$ handling by females and males further modulated the preservation of 2-amino $\mathrm{N}$ under sufficient available energy. The effects of sex were more marked than those of diet were, since different metabolism survival strategies changed substrate partition and fate. The data presented suggest a lower than expected $\mathrm{N}$ flow to the liver, which overall importance for amino acid metabolism tends to decrease with both cafeteria diet and female sex. Under standard conditions, liver availability of ammonium was low and controlled. The situation was unchanged (or even lowered) in cafeteria-fed rats, ultimately depending on intestinal amino acid catabolism

Keywords:

urea cycle; liver; ammonium; cafeteria diet; amino acid metabolism

\section{INTRODUCTION}

There is a considerable body of knowledge on the effect of diet on the substrate energy utilization under different physiological conditions. A growing consensus attributes the wide extension of metabolic syndrome (MS) to sustained excess energy (mainly lipid) diets on the ponderostat system ${ }^{1}$. The most apparent consequence of excess energy being the development of obesity ${ }^{2}$ and their MS-related comorbidities, especially insulin resistance ${ }^{3}$ and the alteration of blood lipid transport ${ }^{4}$.

High-energy diets show markedly different effects depending on the sex (and age) of the subjects 5. In general, females are more resistant to the development of $\mathrm{MS}^{6}{ }^{6}$, in part because of the protective effects of oestrogen 7 , which hampers the obesogenic effects of inflammation and insulin resistance ${ }^{8}$, limiting the full development of obesity ${ }^{9}$. There is a limited antagonism between glucocorticoids and oestrogens ${ }^{10}$, which tend to counteract the increase in fat stores elicited by glucocorticoids ${ }^{11}$. In males, however, the progressive decrease in androgens with age 12 is compounded by the increase in glucocorticoids parallel to the development of MS ${ }^{13}$. Androgen secretion is largely blocked by glucocorticoids, resulting in increased fat storage (obesity, liver steatosis) and a marked alteration of glucose and lipid metabolism, especially in adipose tissue, muscle and liver ${ }^{14}$. 
Our knowledge of how sex influences the deleterious effects of excess energy (lipid) intake with respect to energy expenditure, and inflammation is, however, rather sketchy, since sex-related differences have been observed, but most mechanisms remain to be fully clarified 15,16 .

The liver plays a key role in nutrient partition and in the maintenance of body energy homeostasis. It receives, via porta vein, most of the nutrients extracted from the diet. However, a large part of the sifting has been done, already, by other splanchnic bed organs, especially the intestine ${ }^{17}$, and, probably, mesenteric/ omental adipose tissue ${ }^{18}$. In any case, the liver controls the flow of glucose into the systemic blood, and retains (or metabolizes) many amino acids and short-chain fatty acids. A sustained excess of nutrients and a critical failure of the insulin system may lead to a generalized loss of effectivity of the liver, often provoking hepatic steatosis ${ }^{19}$, associated to insulin resistance ${ }^{20}$. Loss of insulin function resulting also in lower amino acid utilization ${ }^{21}$. The liver condition may even develop in a failure to detoxify the portalcarried ammonium, which may result lethal ${ }^{22}$. Of all these critical functions, the liver -in fact the coordinate work of intestine and liver- plays an essential role in the disposal of excess amino $\mathrm{N}$ and ammonia. The main pathway for excess $\mathrm{N}$ elimination is the urea cycle ${ }^{23,24}$, which has been assumed to be fully operative only in liver ${ }^{25}$. However, both intestine and kidney have functional (albeit complementary) urea cycles ${ }^{26}$, ${ }^{27}$. We have found, recently, a robust presence of urea cycle in white adipose tissue ${ }^{28}$, which is unaffected by sex and anatomical site ${ }^{29}$ ENREF_28.

High-fat diets, such as the cafeteria diets ${ }^{30}$, have been known, to decrease the operation of the urea cycle in liver ${ }^{31}$, with lower overall urinary excretion of $N^{32}$. This decreased excretion, in spite of maintained or increased protein intake, is not paralleled by an increased deposition of protein (or faecal excretion) ${ }^{32}$. In fact, nitrogen balances show that a significant portion of the $\mathrm{N}$ excreted is not accounted for ${ }^{33}$. It has been speculated that it may be justified (at least partly) by respiratory loss of nitric oxide ${ }^{34}$ or, even, release of nitrogen gas ${ }^{35}$.

The control role of the liver on the disposal of ammonium- $\mathrm{N}$ and excess amino- $\mathrm{N}$, is a critical process for the maintenance of $\mathrm{N}$ homeostasis. Thus, alteration of liver metabolic function induced by diet necessarily influences $\mathrm{N}$ homeostasis, albeit in ways so far not known. We assume that this dramatic change may contribute to the pathogenesis of MS. In the present study, we analysed the effects of a relatively short (one-month) exposure of adult rats (female and male) to a cafeteria diet. The objective was to check how the initial phase of development of MS affects, differentially (in adults), both sexes in the critical function of liver as main site for disposal of ammonium through the urea cycle.

\section{EXPERIMENTAL}

Ethics statement

All animal handling procedures and the experimental setup were in accordance with the animal handling guidelines of the corresponding European and Catalan Authorities. The Committee on Animal Experimentation of the University of Barcelona approved the present study.

\section{Experimental design and animal handling}

Nine week old female and male Wistar rats (Harlan Laboratory Models, Sant Feliu de Codines, Spain) were used. The rats $(\mathrm{N}=6)$ were kept in same-sex two-rat cages with wood shards for bedding. The 
animals were maintained in a controlled animal room (lights on from 08:00 to $20: 00 ; 21.5-22.5^{\circ} \mathrm{C} ; 50-60 \%$ humidity). Two groups for each sex were randomly selected and were fed ad libitum, for 30 days, with either normal rat chow (Harlan \#2014) or a simplified cafeteria diet ${ }^{36}$ made of chow pellets, plain cookies, with liver pâté, bacon, whole milk containing $300 \mathrm{~g} / \mathrm{L}$ sucrose and a mineral and vitamin supplement. Food/ nutrient consumption was measured as previously described ${ }^{30}$. Diet intake composition (expressed as energy content) was: carbohydrate $67 \%$, protein $20 \%$, and lipid $13 \%$ for controls: that of rats fed the cafeteria diet (i.e. after computing the food ingested) was (mean values, expressed as energy content): carbohydrate $47 \%$, protein $12 \%$ and lipid $41 \%$. The simplified cafeteria diet induced a significant increase in body fat, in line with previous studies on metabolic syndrome ${ }^{32,36}$. The rats were killed, under isoflurane anaesthesia, by exsanguination (aortic puncture using a large dry-heparinized syringe) at the beginning of a light cycle. Then, they were rapidly dissected, and two lobes of the liver were excised, blotted, and frozen in liquid nitrogen. These samples were weighed and ground under liquid nitrogen. The coarse powder was aliquoted and stored at $-80^{\circ} \mathrm{C}$ until processed. Later, the liver remains were dissected to measure its full weight. Blood was centrifuged to obtain plasma, which was frozen and stored as well.

Blood plasma parameters

Plasma samples were used to measure glucose (kit \#11504, Biosystems, Barcelona Spain), lactate (kit \#1001330, Spinreac, Sant Esteve de Bas, Spain), triacylglycerols and total cholesterol (Biosystems kits $\# 11828$, and \#11505, respectively). Urea was measured with a chemical method (kit \# 11537; Biosystems). Amino acids were analysed individually with an amino acid analyser (LKB-Alpha-plus, Uppsala, Sweden) using plasma samples deproteinized with chilled acetone ${ }^{37}$. Since the method used did not provide reliable data for several amino acids (i.e. GIn, Trp, Cys, Asn), we decided to present only the partial sum of the other amino acids as a single indicative value.

Enzyme activity analyses

Homogenate preparation. Frozen liver samples were further homogenized, using a tissue disruptor (Ultraturrax IKA-T10, Ika Werke, Staufen, Germany). Homogenates for arginino-succinate synthase and ornithine carbamoyl-transferase activity measurement were prepared using 10 volumes of chilled $70 \mathrm{mM}$ hepes buffer pH 7.4 containing $1 \mathrm{mM}$ dithiothreitol (Sigma, St Louis MO USA), $50 \mathrm{mM} \mathrm{KCl}$, $1 \mathrm{~g} / \mathrm{L}$ Triton X-100 (Sigma), and $1 \mathrm{~g} / \mathrm{L}$ lipid-free bovine serum albumin (Sigma). Homogenates for carbamoyl-P synthase analysis were prepared with 10 volumes of chilled $50 \mathrm{mM}$ triethanolamine buffer $\mathrm{pH}$ 8.0 containing $1 \mathrm{mM}$ dithiothreitol, $0.5 \mathrm{~g} / \mathrm{L}$ Triton X-100, $1 \mathrm{~g} / \mathrm{L}$ lipid-free bovine serum albumin and $10 \mathrm{mM}$ magnesium acetate. Homogenates for the analyses of the other enzymes were prepared with 10 volumes of chilled Krebs-Ringer bicarbonate buffer pH 7.4 containing $1 \mathrm{~g} / \mathrm{L}$ Triton X-100, $1 \mathrm{mM}$ dithiothreitol and 1 $\mathrm{g} / \mathrm{L}$ lipid-free bovine serum albumin. The homogenates were coarsely filtered through nylon-hose to eliminate large debris. They were kept on ice and used for enzyme activity analyses within $2 \mathrm{~h}$. Tissue protein content was estimated with the Lowry method ${ }^{38}$, using the corresponding homogenization buffer (containing albumin) as blank. Enzyme activities were expressed per unit of protein weight. The methods used were largely based in our parallel development of methods for analysis on white adipose tissue, extensively described in a previous publication ${ }^{28}$.

Carbamoyl-P synthase 1 activity was estimated from the incorporation of ${ }^{14} \mathrm{C}$-bicarbonate (Perkin Elmer, Bad Neuheim, Germany) into carbamoyl-P using a method previously described by us ${ }^{39}$. Succinctly, we measured the incorporation of label into carbamoyl-P by the activity of the enzyme on ammonium 
carbonate in the presence of $\mathrm{N}$-acetyl-glutamate (Sigma) and flushing out all remaining bicarbonate label with a stream of unlabelled $\mathrm{CO}_{2}$.

Ornithine carbamoyl transferase activity was measured from the reaction of condensation of carbamoyl-P and ${ }^{14} \mathrm{C}$-ornithine to yield ${ }^{14} \mathrm{C}$-citrulline. Aliquots of $25 \mu \mathrm{L}$ of homogenates were mixed with 50 $\mu \mathrm{L}$ of $70 \mathrm{mM}$ hepes buffer $\mathrm{pH} 7.4$ containing carbamoyl-P, ornithine (all from Sigma), and ${ }^{14} \mathrm{C}$-ornithine (Perkin-Elmer); final concentrations were $9 \mathrm{mM}, 13 \mathrm{mM}$ and $1 \mathrm{kBq} / \mathrm{mL}$, respectively. The reaction was started with the homogenate, and was carried out at $37^{\circ} \mathrm{C}$ during $0,0.5,1$ and $2 \mathrm{~min}$. The reaction was stopped by introducing $75 \mu \mathrm{L}$ aliquots in tubes, kept on ice, containing $100 \mu \mathrm{L}$ of chilled acetone. After centrifugation, the clear supernatants were dried in a vacuum-centrifuge (Thermo Scientific, Waltham, MA USA). The residues were dissolved in $25 \mu \mathrm{L}$ of water; they were run on TLC silicagel plates (200 $\mu \mathrm{m}$; Macherey-Nagel, Düren, Germany). Standards of ornithine and citrulline were included in one of the lanes of each plate. The plates were developed with trichloromethane: methanol: acetic acid (1:2:2 by volume). Standards were revealed with a ninhydrin spray. The lanes were cut in $1 \mathrm{~cm}$ pieces and counted. The label in the citrulline spot was expressed as a percentage of the total label counted in each TLC lane. These data allowed the calculation of newly formed citrulline at each incubation time. The $V_{0}$ value for each sample was plotted, and was considered to represent the value of $\mathrm{V}_{\max }$ under the conditions tested.

Arginino-succinate synthase activity was measured from the reaction of condensation of aspartate with citrulline in the presence of ATP to yield arginino-succinate. Homogenates $(55 \mu \mathrm{L})$ were mixed with $30 \mu \mathrm{L}$ of $70 \mathrm{mM}$ hepes buffer $\mathrm{pH} 7.4$, containing ATP-Na2, $\mathrm{MgCl}_{2}$, citrulline and aspartate (Sigma); final concentrations were $10 \mathrm{mM}, 5 \mathrm{mM}, 3 \mathrm{mM}$, and $2.5 \mathrm{mM}$, respectively. The reaction was started with aspartate, and was carried out at $37^{\circ} \mathrm{C}$. The reaction was stopped with $40 \mu \mathrm{L}$ of $30 \mathrm{~g} / \mathrm{L}$ perchloric acid. The tubes were vortexed and neutralized ( $\mathrm{pH} 7-8$ ) with $10 \mu \mathrm{L}$ of $100 \mathrm{~g} / \mathrm{L} \mathrm{KOH}$ containing $62 \mathrm{~g} / \mathrm{L} \mathrm{KHCO}$. The tubes were vortexed again and centrifuged in the cold $15 \mathrm{~min}$ at 8,000xg. The aspartate remaining in the supernatants was measured by transamination to oxaloacetate, which was reduced by malate dehydrogenase and NADH. Briefly, $20 \mu \mathrm{L}$ of the supernatants were brought up to $300 \mu \mathrm{L}$ in 96 -well plates, with $66 \mathrm{mM}$ phosphate buffer $\mathrm{pH} 7.4$ containing NADH, 2-oxoglurarate, aspartate transaminase (pig heart) and malic acid dehydrogenase (pig heart) (all from Sigma); final concentrations were, respectively, 0.25 $\mathrm{mM}, 0.2 \mathrm{mM}, 20 \mu \mathrm{kat} / \mathrm{L}$ and $17 \mu \mathrm{kat} / \mathrm{L}$. The plates were read at $340 \mathrm{nM}$ in a plate reader (Biotek, Winoosky, VT USA) at intervals of $30 \mathrm{~s}$ during $20 \mathrm{~min}$. The fall in NADH was used to determine the levels of aspartate at each incubation time. Its disappearance (versus time zero levels) was used to calculate the aspartate incorporated into arginino-succinate by the enzyme.

Arginino-succinate lyase activity was measured from the breakup of arginino-succinate to yield fumarate and arginine. This amino acid was analysed in a second reaction, using arginase to form ornithine and urea, which was measured using a sensitive chemical method. Aliquots of $38 \mu \mathrm{L}$ of homogenates were mixed with $38 \mu \mathrm{L}$ of $66 \mathrm{mM}$ hepes buffer $\mathrm{pH} 7.4$, containing arginino-succinate (Sigma), at a final concentration $2 \mathrm{mM}$. Incubations were carried out at $37^{\circ} \mathrm{C}$ for $0,2.5,5$ and $10 \mathrm{~min}$. The reaction was stopped by the addition of $40 \mu \mathrm{L}$ of $30 \mathrm{~g} / \mathrm{L}$ perchloric acid. The tubes were vortexed and brought to $\mathrm{pH}$ 8-9 with $10 \mu \mathrm{L}$ of $100 \mathrm{~g} / \mathrm{L} \mathrm{KOH}, 80 \mathrm{~g} / \mathrm{L} \mathrm{HKCO}_{3}$. The tubes were centrifuged for $15 \mathrm{~min}$ in the cold at 8,000xg. Aliquots of $100 \mu \mathrm{L}$ of the supernatants were mixed with $50 \mu \mathrm{L}$ of the reacting mixture, containing $66 \mathrm{mM}$ hepes buffer $\mathrm{pH} 7.5$ (to achieve a final $\mathrm{pH}$ 8.5), $\mathrm{MnCl}_{2}$ and arginase (rat liver, Lee Biosolutions, St Louis, MO USA). The final concentrations were $7 \mathrm{mM}$ and $17 \mu \mathrm{kat} / \mathrm{L}$, respectively. Arginase already in the buffer 
containing $\mathrm{Mn}^{2+}$, was previously activated for $5 \mathrm{~min}$ at $55^{\circ} \mathrm{C}$. The reaction developed for $30 \mathrm{~min}$ at $37^{\circ} \mathrm{C}$, and was stopped by the addition of $35 \mu \mathrm{L}$ of $160 \mathrm{~g} / \mathrm{L}$ perchloric acid. The tubes were centrifuged in the cold for $15 \mathrm{~min}$ at $8,000 \mathrm{xg}$. The acidic supernatants $(175 \mu \mathrm{L})$ were used for the estimation of urea. They were mixed with $600 \mu \mathrm{L}$ of $90 \mathrm{~g} / \mathrm{L} \mathrm{H}_{2} \mathrm{SO}_{4}$ containing $270 \mathrm{~g} / \mathrm{L} \mathrm{H}_{3} \mathrm{PO}_{4}$; then $10 \mu \mathrm{L}$ of $30 \mathrm{~g} / \mathrm{L}$ of 1-phenyl-2-oxime-1, 2-propanodione (Sigma) in absolute ethanol were added. The reaction was developed at $100^{\circ} \mathrm{C}$ for $30 \mathrm{~min}$ in a dry block heater. The absorbance of the tubes (including standards and blanks) was measured at 540 $\mathrm{nm}$ with a plate reader. Arginase effectivity (using the method explained in 2.3.6) was tested in all batches. In all cases, conversion of arginine to urea was $100 \%$ (i.e. there was a full coincidence of the standard curves for both urea and arginine).

Arginase activity was measured through the estimation of the urea produced by the activity of the enzyme on arginine in the presence of $\mathrm{Mn}^{2+}$ ions ${ }^{40,41}$. Aliquots of $20 \mu \mathrm{L}$ of homogenates were mixed with $5 \mu \mathrm{L}$ of $\mathrm{MnCl}_{2}$ in water; final concentration $10 \mathrm{mM}$. The tubes were heated for $5 \mathrm{~min}$ at $55^{\circ} \mathrm{C}$ to activate arginase ${ }^{41,42}$ After the temperature was brought down to $37^{\circ} \mathrm{C}$, the reaction began with the addition of 75 $\mu \mathrm{L}$ of arginine (Sigma); final concentration $78 \mathrm{mM}$. Incubations were carried out for 0,8 and $16 \mathrm{~min}$ at 37 ${ }^{\circ} \mathrm{C}$. The reaction was stopped by the addition of $35 \mu \mathrm{L} 160 \mathrm{~g} / \mathrm{L}$ perchloric acid. The tubes were centrifuged $15 \mathrm{~min}$ in the cold at 8,000xg. Urea was measured as described above.

Glutamine synthetase, activity was estimated using a method we had used previously ${ }^{43}$, based on the reaction of glutamine and hydroxylamine in the presence of $\mathrm{ADP}, \mathrm{Mn}^{2+}$ and arsenate to yield $\mathrm{Y}$ glutamyl-hydroxamate. The addition of $\mathrm{Fe}\left(\mathrm{NO}_{3}\right)_{3}$ in trichloroacetic acid results in the development of colour, read at $500 \mathrm{~nm}$ using a plate reader.

Serine dehydratase activity was analysed, by measuring the pyruvate freed by the enzyme in the presence of pyridoxal- $\mathrm{P}^{44}$. This reaction was coupled with the reduction of pyruvate to lactate with lactate dehydrogenase, measuring the decrease in $\mathrm{NADH}^{45}$, by UV spectrometry using a plate reader.

AMP deaminase activity was estimated by the determination of the ammonium released by the action of the enzyme on AMP, in the presence of $\mathrm{KCl}$, yielding IMP ${ }^{46}$. The ammonium evolved was estimated with the classical Berthelot indophenol reaction ${ }^{47}$, in which indophenol was formed by reaction of ammonium with phenol in the presence of an oxidative agent (hypochlorite) and nitroprusside as catalyser.

Gene expression analysis

Total tissue RNA was extracted from frozen samples (about $30 \mathrm{mg}$ ) using the GenEluteTM (SigmaAldrich, St Louis MO USA) procedure, and was quantified in a ND-100 spectrophotometer (Nanodrop Technologies, Wilmington DE USA). RNA samples were reverse transcribed using the MMLV reverse transcriptase (Promega, Madison, WI USA) system and oligo-dT primers. The data were also used to determine the total RNA content of the tissue in order to establish quantitative comparisons between different gene expressions.

Real-time PCR (RT-PCR) amplification was carried out using $10 \mu \mathrm{L}$ amplification mixtures containing Power SYBR Green PCR Master Mix (Applied Biosystems, Foster City, CA USA), 10 ng of reverse-transcribed RNA and primers (300 nM). Reactions were run on an ABI PRISM $7900 \mathrm{HT}$ detection system (Applied Biosystems) using a fluorescent threshold manually set to 0.15 for all runs. 
A semi-quantitative approach for the estimation of the concentration of specific gene mRNAs per unit of tissue or protein weight was used ${ }^{48}$. Cyclophyllin A (Ppia) was used as charge control gene ${ }^{49}$. The data were expressed as the number of transcript copies per gram of protein in order to obtain comparable data between the groups. The genes analysed, and a list of primers used, are presented in Table 1.

The possible contamination of RNA with DNA was checked, before PCR cycling, by charging a number of samples of each batch with known internal standards of RNA. No spurious signals were observed. All the primers used for measurement of the enzyme gene expressions were checked, with Northern blots of the PCR-synthesized cDNAs. In all cases, the cDNAs obtained had the expected molecular weights.

Total DNA was estimated with a fluorimetric method ${ }^{50}$. Approximate cellularity was calculated, assuming that the mean mammalian cell DNA content was $6 \mathrm{pg}{ }^{51}$. Mean cell volume was estimated from liver weight, liver density: $1.1 \mathrm{~g} / \mathrm{mL}$, and the estimated number of cells.

\section{Statistics}

Two-way ANOVA comparisons between groups, correlations and curve fitting (including $V_{1}$ estimations) were carried out with the Prism 5 program (GraphPad Software, San Diego CA USA).

\section{RESULTS}

\section{General parameters}

Table 2 presents the rat weights, and liver size and composition of the four groups of rats. As expected, body and liver weight were affected by sex and diet. However, liver weight was maintained at about $3.1-3.3 \%$ of body weight in all groups. Whole-liver cellularity was (mean values for groups, in $10^{9}$ cells): 4.0 and 4.9 for control and cafeteria males, as well as 2.4 and 2.7 for control and cafeteria females. Estimated cell size was higher in females: 3.3 and $3.2 \mathrm{ng} / \mathrm{cell}$ in control and cafeteria rats, respectively, versus 2.9 and $2.8 \mathrm{ng} / \mathrm{cell}$ in males ( $\mathrm{P}<0.05$ for both diets). However, no overall significant effects of diet and sex were observed for DNA content in $\mathrm{mg} / \mathrm{g}$ tissue.

Concentrations of protein and RNA in liver were affected by sex; males had higher protein and females had higher RNA concentrations; but no significant effects of diet were observed. RNA/DNA ratios were, again, not affected by diet, but sex resulted in higher values $(P<0.05)$ for females $(3.2$ controls and 3.0 cafeteria) than males ( 2.4 for both dietary groups).

Table 3 shows the main plasma energy parameters of the rats. Glucose levels were increased, and those of lactate decreased, significantly by feeding the cafeteria diet. Cholesterol was unaffected by either sex or diet. Triacylglycerols, however, were affected by sex (but not by diet), with female values being higher than those of males, especially in control rats. The sum of plasma amino acids was also affected by sex (with females showing higher combined levels). Finally, urea concentrations were decreased by cafeteria diet, but were overall higher in female rats.

Urea cycle

Figure 1 depicts a scheme of the urea cycle in liver, showing the enzyme activities (and their corresponding gene expressions) for ornithine carbamoyl-transferase, arginino-succinate synthase, arginino-succinate lyase and arginase 1 . The Figure shows also the expressions of the genes coding for 
endothelial nitric oxide synthase and $\mathrm{N}$-acetyl-glutamate synthase (acetyl-transferase). Arginase activity was about three orders of magnitude higher than those of the arginino-succinate enzymes; ornithine carbamoyl-transferase activity was also high, but only one order of magnitude higher than those of the arginino-succinate enzymes. These extreme differences in activity were less marked when comparing the expressions of the four enzymes, since all were in the same range except arginino-succinate synthase, one order of magnitude higher. These differences resulted in disparate activity/expression ratios.

The patterns of activity were similar for all four enzymes, but there were significant effects of sex only in arginino-succinate synthase and arginase, and of diet in these same enzymes plus argininosuccinate lyase. The patterns for gene expression of the urea cycle enzymes were also similar and followed the same profile than their corresponding enzyme activities. Sex affected only (i.e. significantly) the expression of arginino-succinate synthase. The expression of their corresponding genes was affected by diet in the same enzyme plus arginino-succinate lyase and arginine. In all enzymes of Figure 1, except ornithine carbamoyl-transferase, both activities and expressions were decreased in cafeteria diet-fed rats vs. controls.

The possible direct relationship between gene expression and enzyme activity (unaffected by posttranslational modification) was checked analysing the correlation between the data for both parameters of all animals studied, irrespective of sex and diet (i.e. $\mathrm{N}=24$ ). There were significant correlations between enzyme activity and expression for arginino-succinate synthase $\left(R^{2}=0.283 ; P=0.023\right)$, arginase 1 $\left(R^{2}=0.184 ; P=0.037\right)$, carbamoyl-P synthase $\left(R^{2}=0.440 ; P=0.0008\right)$ and serine dehydratase $\left(R^{2}=0.635\right.$; $\mathrm{P}=0.0002)$. No significant correlations were found for any of the other enzymes studied.

Acetylation of glutamate was also affected by diet, following the same pattern described above. The expression of endothelial nitric oxide synthase showed a clear effect of sex, with higher values in females but the effects of diet were not significant.

\section{Ammonium metabolism}

Figure 2 shows a general outline of liver ammonium metabolism, including the activities of carbamoyl-P synthase 1, serine dehydratase, AMP deaminase and glutamine synthetase, as well as the expressions of their corresponding genes. The Figure includes, also the expressions of glutaminase, the cytoplasmic (NADPH-dependent) glutamate dehydrogenase and a component of the glycine cleavage system (H protein).

Carbamoyl-P synthetase 1 showed higher enzyme activities in females; these effects were not observed in its gene expression, which presented considerable variability. AMP deaminase showed no significant effects of sex or diet on activity or gene expression. The activity of serine dehydratase was markedly affected by sex, with lower female values, an effect that was parallel to the changes in gene expression. Diet also affected the gene expression of serine dehydratase, with values even lower for cafeteria-fed rats.

Glutamine synthetase activity in females was higher than in males, a difference also observed in the expression of its gene. Glutaminase expression did not show effects of sex, but cafeteria diet decreased the expression of the enzyme. This pattern was paralleled by glutamate dehydrogenase, which also showed an effect of sex (higher values in females). The expression of the glycine cleavage system (in fact that of representative $\mathrm{H}$ protein) was strongly influenced by sex, with -again — higher values in female rats 


\section{DISCUSSION}

We have shown evidence that both sex and diet, rather independently, affected the activities and gene expressions of the urea cycle enzymes in rat liver. However, this apparent similarity of effect shifts towards more extensive effects of sex on the management of ammonium in the liver, thus affecting, albeit indirectly, the overall operation of the urea cycle and the final excretion of $\mathrm{N}$ as urea. The model used behaved as expected both in increased WAT fat deposition 52,53 and relative normalcy of plasma parameters, including insulin ${ }^{54}$ as repeatedly found under these same conditions in previous studies ${ }^{32,36}$.

We used a cafeteria diet model well studied by us previously, which shows a discrete increase in body weight due to the accumulation of fat, but the metabolic alterations induced by inflammation in the context of MS are essentially incipient ${ }^{52,55}$. The effects are strongly influenced by sex ${ }^{56}$; a question that we also found applies to amino acid metabolism ${ }^{29}$. The obesogenic effects of cafeteria diets are maximal during early postnatal development ${ }^{57}$, preventing the weaning shift from a high fat to a high carbohydrate diet ${ }^{58}$. The timing and extent of exposure are critical to enhance the ability of this type of diets to induce MS 56,59 ._ENREF_52 We used young adult rats, and subjected them to a moderate exposure time to the hyperlipidic diet in order to obtain not a frankly pathological state but a pre-MS situation in which the immediate effects of the high-energy diet are not confounded by the additional disorders elicited by a severe inflammation ${ }^{60,61}$.

The so far scarcely studied effect of sex on amino acid catabolism may have deeper roots than usually assumed. The lack of direct studies on the mechanisms has driven our attention to the overall picture of effects of sex on amino-N economy. In males, the main trend is accumulation of body protein, largely muscle, an effect facilitated by insulin ${ }^{62}, \mathrm{GH}$ and androgens ${ }^{63}$, and hampered by glucocorticoids ${ }^{64}$. In females, however, the main drive seems to be somewhat different: to enhance $\mathrm{N}$ sparing probably to fulfil the burden of reproduction, first the foetuses, and then the energy economy ordeal of lactation. In both sexes, in addition, the overall trend to preserve amino- $N$ is a primeval drive that prevents its wasting 65,66 even under (rare in Nature) conditions of dietary excess of protein ${ }^{67}$. We can speculate that androgen predominance (i.e. in males), acting as counterbalance to glucocorticoids, may diminish the hepatic conversion of amino acid $\mathrm{N}$ to urea; oestrogen (i.e. in females) showing a less marked influence on this aspect.

Enzyme activities are not direct estimations of the enzyme function within the cell, but are a widely accepted correlate of the overall enzyme ability to carry out its function. Thus, the $V_{i}$ values presented are a correlate of $V_{\max }$ and of functional protein enzyme levels. These values, consequently; reflect potential ability of the tissue to catalyse the reaction, albeit being estimated under result-maximizing nonphysiological conditions. The closeness of gene expression patterns and enzyme activities mutually support the data presented. However, the large differences in activity observed between enzymes (i.e. arginase vs. arginino-succinate synthase) but also between expression and activity may be a consequence of different turnover number or enzyme (as protein) turnover ${ }^{68}$, but place the control of the cycle, precisely on these key enzymes. In arginino-succinate synthase as rate limiting step ${ }^{69}$; and arginase as final factor in the release of urea ${ }^{70}$, but also as the main site for arginine break-up and maintenance of body arginine-citrulline equilibrium ${ }^{71}$. In the urea cycle, $\mathrm{N}$ disposal and guanido-amino acid maintenance for their multiple regulatory tasks intermix to a considerable extent, as can be deduced from the model presented here. The 
different needs for arginine possibly modulate the sex differences in expression, but the enzyme activities follow more closely the regulation mechanisms for $\mathrm{N}$ handling.

It has been known for long, that urea production is decreased by diets rich both in energy and in protein ${ }^{31}$, assumedly because of lower urea cycle enzyme activities in the liver. Our results are consistent with this observation, but, at the same time, we provide evidence that these differences, largely downregulation of enzyme activities, were described, essentially, in males. No sufficient data for comparison is available for females. This is best observed in the halving of three key enzyme activities in males by feeding a cafeteria diet: arginino-succinate synthase, arginino-succinate lyase and arginase. Of these, female rats maintained only the effect on arginino-succinate lyase; thus, males' downregulation may be traced to more control points than females, which may help explain the sex-related differences in regulation described above. The consequences on overall function of the cycle are consistent with the lower urea production observed in rats fed a cafeteria diet, in studies using mainly males $31,32,72$.

The relatively low and largely unchanged expression of endothelial nitric oxide synthase suggests a relatively low activity, compared with arginase, in their competence for arginine, an effect best seen in peripheral tissues ${ }^{73}$. In the present study, the expression of the enzyme did not change significantly at all, which seems to disconnect this enzyme from the main hepatic degradative pathway represented by the urea cycle. The fate of the "unaccounted for" dietary nitrogen i.e. that portion of dietary $\mathrm{N}$ not excreted in urine (mainly urea) or faeces, and neither accumulated in body protein does not seem, thus, to be related to changes in the capacity of liver for higher nitric oxide synthesis. Limiting its contribution to the excess nitric oxide production caused by metabolic syndrome and/or cafeteria diet feeding 33,74 .

Liver ability to synthesize citrulline was not decreased by diet, which suggests that liver may also contribute to the overall production of citrulline ${ }^{75}$, as that observed in adipose tissue ${ }^{29}$. The relative inability of the liver to retain and process citrulline ${ }^{75}$ hints at this amino acid not being, in the liver, a critical factor in the regulation of the cycle, in addition to its overall importance for arginine metabolism regulation ${ }^{76}$.

It has been generally assumed that ammonia arriving to the liver (and that produced in its own catabolism of amino acids) is a main factor for the control of its disposal through the urea cycle ${ }^{77,78}$. It is obvious that the liver is a formidable barrier that prevents ammonium from entering the systemic circulation and thus possibly damaging the nervous system ${ }^{79}$. The liver counts not only with the urea cycle (essentially carbamoyl-P synthase 1 ) to incorporate it into urea with amino- $N$ taken from aspartate, but also with two additional and powerful ammonium-handling systems (and nitrogen salvage ${ }^{80}$ ): glutamine synthetase ${ }^{81}$, and glutamate dehydrogenases ${ }^{82}$ within the mitochondrion and in the cytoplasm. Compartmentation of ammonium/ ammonia in the cell is also an important ${ }^{83}$ aspect that has not been sufficiently studied.

Carbamoyl-P synthases convert ammonium (or glutamine amido $\mathrm{N}$ ) into carbamoyl-P in liver, were practically only the isozyme 1 has significant activity ${ }^{84}$. The reaction provides carbon and nitrogen to start the formation of the guanido group on ornithine, via ornithine carbamoyl-transferase. Following the trend described for the urea cycle enzymes, no differences were observed in gene expressions but cafeteria diet slightly decreased the enzyme activity in both sexes. These differences support the overall function of the cycle described above, since this enzyme incorporation of ammonia is a key control point in the synthesis of urea ${ }^{78}$.

The existence of significant correlations between activity and expression for carbamoyl-P synthase and the key regulatory urea cycle enzymes arginino-succinate synthase and arginase, attest to a direct 
translational control of the urea cycle in liver. As indicated above, these three enzymes have been postulated as main control points for urea cycle operation. It is worth noting that only these enzymes, and serine dehydratase, which gene expression is controlled only by serine availability ${ }^{85}$, showed a direct (statistically significant) relationship between expression and measured enzyme activity. Since the analyses have been done under different dietary and sex conditions, the maintenance of this basic process shows that regulation of gene translation is a key mechanism of control of the cycle.

The liver is a main site for amino acid partition and $\mathrm{N}$ disposal. This is a consequence of its peculiar placement, at the end of the portal system, which carries the $\mathrm{N}$ debris of intestinal and microbiota catabolism, modulated by intestinal function ${ }^{86}$. In addition, liver has the advantage of using the ammonia evolved from catabolic reactions directly in its cells. Glutamine synthetase is placed essentially in the perivenous cells ${ }^{87}$, acting as last defence barrier against release of ammonium into the systemic circulation; this enzyme shows a marked sex difference. $\mathrm{NADP}^{+}$-glutamate dehydrogenase showed a similar pattern with respect to sex, but cafeteria diet tended to decrease its expression. Since glutamate dehydrogenase is assumed to act (in the liver) mainly in the direction of glutamate synthesis ${ }^{82,88}$, its increase in females agrees with the hypothesis of their enhanced focussing on amino-N sparing.

The significant (from a quantitative point of view) functional urea cycle in white adipose tissue introduces a critical question on the primacy of liver in overall 2-amino $N$ disposal 28 , 29. Probably, the main role of adipose tissue urea cycle is complementary to that of liver, providing arginine and citrulline to the rest of the body ${ }^{28}$ and, perhaps acting as backup system for the liver amino- $\mathrm{N}$ elimination. The limited effect of diet on the urea cycle of adipose tissue ${ }^{28,29}$ contrasts with the marked effects observed here in liver, and help support the hypothesis that the function of the cycle is not subjected to the same parameters of control, nor, probably, shares the same metabolic function in both organs.

The main liver ammonium producing mechanisms are the purine nucleotide cycle ${ }^{89}$, i.e. AMP deaminase ${ }^{90}$, glutaminase ${ }^{91}$, serine (and threonine) dehydratase ${ }^{92}$ and the glycine cleavage system ${ }^{93}$. There are other sources, such as amino- and amino acid oxidases and a number of enzymes acting on the catabolism of essential amino acids, but the nature of the $\mathrm{N}$ donors suggest a conjointly limited contribution to the liver ammonium pool. However, a main source is the ammonia/ ammonium carried from the intestine (and microbiota) by the portal blood ${ }^{94}$.

The role of AMP deaminase in liver is more complex than its simple participation in the purine nucleotide cycle ${ }^{95}$, since it is part of the purine salvage pathway ${ }^{96}$. In addition, the enzyme breaks up the AMP generated by adenylate kinase under conditions of scarcity of ATP or nutrients ${ }^{97}$, as a way to control glycolysis, often in conjunction with ammonium production ${ }^{98}$. Breakup of AMP to IMP also affects AMPkinases and their control of energy partition ${ }^{99}$. The varied functions of AMP-deaminase in liver, do not seem to include a significant role in the in situ production of ammonium ${ }^{100}$, a condition largely different from that of the muscle enzyme, which places the purine nucleotide cycle as a main mechanism for mineralization of amino-N 101

The analysis of diet/sex effects on serine dehydratase are consistent with a sex-related preservation of amino- $\mathrm{N}$ in females, enhanced by the additional protective effects of cafeteria diet. Serine dehydratase is a classic example of substrate-controlled expression/ activity ${ }^{85}$, and thus, both are correlated. The expression of protein $\mathrm{H}$ of the glycine cleavage system showed, again an effect of sex. Glycine is also a by-product of serine, thus its probable increase in cleavage may not only represent a way 
of amino- $\mathrm{N}$ disposal, but a much needed source of $1 \mathrm{C}$ fragments for synthesis ${ }^{102}$, especially under conditions of excess energy and amino acids.

It may be assumed that, under conditions of sufficient glucose and energy availability (controls) or in their excess (compounded by the presence of large amounts of lipid in cafeteria diet), amino acid metabolism must be hampered in intestine (and liver) by the ultimate need to preserve amino- $\mathrm{N}^{103}$. In consequence, it is probable that the porta vein ammonia would not be increased by cafeteria diet. The final picture, then, could be summarized in a controlled, relatively low, availability of ammonium in the liver under standard conditions, which may be unchanged or even lowered in cafeteria-fed rats, depending on intestinal amino acid catabolism ${ }^{94}$.

\section{CONCLUSIONS}

The effects observed, both in enzyme activities and expressions contributing to remove ammonium and those producing it tend to run in a way similar to that described for the urea cycle: a generalized downregulation of amino acid metabolism ${ }^{72}$. This conclusion is in agreement with a decreased urea production, and markedly contrasts with the actually higher availability of 2-amino $\mathrm{N}$ in the rats fed a cafeteria diet ${ }^{104}$.

This complex intertwining of mechanisms is affected by sex, in a way that the different strategies of amino- $\mathrm{N}$ handling by females and males further modulate the preservation of 2-amino- $\mathrm{N}$ when sufficient energy is available. The sex-related differences are important both in direction and in extension, and open new avenues for understanding how amino acids are used for energy, but also how survival and/or sexrelated metabolism strategies modify substrate partition and fate.

The confrontation between amino- $\mathrm{N}$ preservation and the need to dispose of its excess seem to show a winning hand for preservation as all the data presented above suggest. However, elimination of excess $\mathrm{N}$ is necessary and cannot be easily carried out through the metabolic pathways we know. However, the experimental data show that excess $N$ is removed. The problem is that we have not yet identified which (necessarily major) pathway is used for that elimination, so far, we can only add that it is not urea, and also that the main agent does not seem to be the liver. In any case, the critical question of the fate of the 2amino $\mathrm{N}$ ingested but not excreted (faeces, urine) or accrued in the body of rats fed a high-energy proteinrich self-selected (cafeteria) diet, remains open.

\section{Acknowledgements}

This study was financed in part, by grants of the Plan Nacional de Investigación en Biomedicina (SAF2012-34895) and the Plan Nacional de Ciencia y Tecnología de los Alimentos (AGL-2011-23635) of the Government of Spain. It also counted with the collaboration of the CIBER-OBN Research Web. Silvia Agnelli obtained a Leonardo da Vinci fellowship, and Sofía Arriarán was the recipient of a predoctoral fellowship of the Catalan Government, in both cases covering part of the time invested in this study.

The Authors declare that they have no conflict of interests.

\section{REFERENCES}


1. M. Alemany, Nutr. Res., 2013, 33, 1-11.

2. A. Sclafani and D. Springer, Physiol. Behav., 1976, 17, 461-471.

3. J. P. Felber, E. Haesler and E. Jéquier, Diabetologia, 1993, 36, 1221-1229.

4. J. P. Després, Baillière's Clin. Endocrinol. Metab., 1994, 8, 629-660.

5. X. Wang, J. W. Choi, T. S. Oh, D. K. Choi, R. Mukherjee, H. Liu and J. W. Yun, Proteomics, 2012, 12, 284-299.

6. M. R. Meyer, D. J. Clegg, E. R. Prossnitz and M. Barton, Acta Physiol., 2011, 203, 259-269.

7. T. M. d'Eon, S. C. Souza, M. Aronovitz, M. S. Obin, S. K. Fried and A. S. Greenberg, J. Biol. Chem., 2005, 280, 35983-35991.

8. R. E. Stubbins, K. Najjar, V. B. Holcomb, J. Hong and N. P. Núñez, Diabet. Obes. Metabol., 2012, 14, 58-66.

9. R. E. Stubbins, V. B. Holcomb, J. Hong and N. P. Núñez, Eur. J. Nutr., 2012, 51, 861-870.

10. H. Gong, M. J. Jarzynka, T. J. Cole, J. H. Lee, T. Wada, B. Zhang, J. Gao, W. C. Song, D. B. DeFranco, S. Y. Cheng and W. Xie, Cancer Res., 2008, 68, 7386-7393.

11. C. Asensio, P. Muzzin and F. Rohner-Jeanrenaud, Int. J. Obesity, 2004, 28, S45-S52.

12. L. Antonio, F. C. W. Wu, T. W. O'Neill, S. R. Pye, E. L. Carter, J. D. Finn, M. K. Rutter, M. R. Laurent, I. T. Huhtaniemi, T. S. Han, M. E. J. Lean, B. G. Keevil, N. Pendleton, G. Rastrelli, G. Forti, G. Bartfai, F. F. Casanueva, K. Kula, M. Punab, A. Giwercman, F. Claessens, B. Decallonne and D. Vanderschueren, J. Clin. Endocrinol. Metab., 2015, 100, 1396-1404.

13. M. Wang, Nutr. Metab., 2005, 2, 3.

14. M. Alemany, Front. Endocrinol. (Lausanne), 2012, 3, 27.

15. M. E. Estrany, A. M. Proenza, M. Gianotti and I. Lladó, Cell Biochem. Funct., 2013, 31, 504-510.

16. H. Yokomizo, T. Inoguchi, N. Sonoda, Y. Sasaki, Y. Maeda, T. Inoue, E. Hirata, R. Takei, N. Ikeda, M. Fujii, K. Fukuda, H. Sasaki and R. Takayanagi, Am. J. Physiol., 2014, 306, E1163-E1175.

17. T. Aikawa, H. Matsutaka, H. Yamamoto, T. Okuda, E. Ishikawa, T. Kawano and E. Matsumura, J. Biochem., 1973, 74, 1003-1017.

18. Y. Eguchi, T. Eguchi, T. Mizuta, Y. Ide, T. Yasutake, R. Iwakiri, A. Hisatomi, I. Ozaki, K. Yamamoto, Y. Kitajima, Y. Kawaguchi, S. Kuroki and N. Ono, J. Gastroenterol., 2006, 41, 462-469.

19. M. Carmiel-Haggai, A. I. Cederbaum and N. Nieto, FASEB J., 2005, 19, 136-138.

20. G. Marchesini, M. Brizi, A. M. Morselli-Labate, G. Bianchi, E. Bugianesi, A. J. McCullough, G. Forlani and N. Melchionda, Am. J. Med., 1999, 107, 450-455.

21. G. Bianchi, G. Marchesini, N. Brunetti, E. Manicardi, F. Montuschi, R. Chianese and M. Zoli, Dig. Liver Dis., 2003, 35, 722-727.

22. A. H. Lockwood, J. M. McDonald, R. E. Reiman, A. S. Gelbard, J. S. Laughlin, T. E. Duffy and F. Plum, J. Clin. Invest., 1979, 63, 449-460. 
24. H. A. Krebs, R. Hems, P. Lund, D. Halliday and W. W. C. Read, Biochem. J., 1978, 176, $733-737$.

25. M. Takiguchi, T. Matsubasa, Y. Amaya and M. Mori, Bioessays, 1989, 10, 163-166.

26. A. Aperia, O. Broberger, A. Larsson and K. Snellman, Scand. J. Clin. Lab. Invest., 1979, 39, 329336.

27. P. K. Davis and G. Y. Wu, Comp. Biochem. Physiol., 1988, 119B, 527-537.

28. S. Arriarán, S. Agnelli, X. Remesar, J.-A. Fernández-López and M. Alemany, RSC Adv., 2015, 5, 93403-93414.

29. S. Arriarán, S. Agnelli, X. Remesar, J. A. Fernández-López and M. Alemany, PeerJ, 2015, 3, e1399.

30. E. Prats, M. Monfar, R. Iglesias, J. Castellà and M. Alemany, Physiol. Behav., 1989, 45, $263-272$.

31. T. Barber, J. R. Viña, J. Viña and J. Cabo, Biochem. J., 1985, 230, 675-681.

32. D. Sabater, S. Agnelli, S. Arriarán, J. A. Fernández-López, M. M. Romero, M. Alemany and X. Remesar, BioMed Res. Int., 2014, 2014.

33. M. Esteve, I. Rafecas, X. Remesar and M. Alemany, Biochem. Int., 1992, 26, 687-694.

34. C. Bucca, A. Cicolin, G. Guida, E. Heffler, L. Brussino and G. Rolla, J. Breath Res., 2012, 6, 027104.

35. G. Costa, L. Ullrich, F. Kantor and J. F. Holland, Nature, 1968, 218, 546-551.

36. R. Ferrer-Lorente, C. Cabot, J. A. Fernández-López and M. Alemany, Life Sci., 2005, 77, 20512058.

37. L. Arola, E. Herrera and M. Alemany, Anal. Biochem., 1977, 82, 236-239.

38. O. H. Lowry, R. W. Rosebrough, A. L. Farr and R. J. Randall, J. Biol. Chem., 1951, 193, $265-275$.

39. S. Arriarán, S. Agnelli, J. A. Fernández-López, X. Remesar and M. Alemany, J. Enzyme Res., 2012, 3, 29-33.

40. R. T. Schimke, Methods Enzymol., 1970, 17, 313-317.

41. E. L. Oginsky, Methods Enzymol., 1957, 3, 639-643.

42. D. M. Greenberg, Enzymes, 1960, 4, 257-267.

43. L. Arola, A. Palou, X. Remesar and M. Alemany, Horm. Metabol. Res., 1981, 13, $199-202$.

44. A. Palou, M. Alemany, L. Arola and X. Remesar, Rev. Esp. Fisiol., 1980, 36, 151-154.

45. E. Ishikawa, T. Ninagawa and M. Suda, J. Biochem., 1965, 57, 506-513.

46. N. Ogasawara, H. Goto and T. Watanabe, FEBS Lett., 1974, 44, 63-66.

47. J. K. Fawcett and J. E. Scott, J. Clin. Pathol., 1960, 13, 156-159.

48. M. M. Romero, M. M. Grasa, M. Esteve, J. A. Fernández-López and M. Alemany, Nutr. Metab., $2007,4,26$.

49. J. Q. He, A. J. Sandford, I. M. Wang, S. Stepaniants, D. A. Knight, A. Kicic, S. M. Stick and P. D. Paré, Eur. Respir. J., 2008, 32, 755-762.

50. R. Vytašek, Anal. Biochem., 1982, 120, 243-248.

51. GSP Consortium, Nature, 2004, 428, 493-521. 
52. S. Arriarán, S. Agnelli, D. Sabater, X. Remesar, J. A. Fernández-López and M. Alemany, PLoS One, 2015, 10, e0119572.

53. M. d. M. Romero, S. Roy, K. Pouillot, M. Feito, M. Esteve, M. d. M. Grasa, J.-A. Fernández-López, M. Alemany and X. Remesar, PLoS One, 2014, 9, e90995.

54. R. Ferrer-Lorente, C. Cabot, J. A. Fernández-López and M. Alemany, N.-S. Arch. Pharmacol., 2010, 381, 339-348.

55. D. Sabater, S. Agnelli, S. Arriarán, J.-A. Fernández-López, M. d. M. Romero, M. Alemany and X. Remesar, BioMed Res. Int., 2014, 2014, 959420.

56. R. Díaz-Rúa, E. García-Ruiz, A. Caimari, A. Palou and P. Oliver, Food Funct., 2014, 5, 3117-3131.

57. H. Castro, C. A. Pomar, C. Picó, J. Sánchez and A. Palou, Int. J. Obesity, 2015, 39, 430-437.

58. M. Alemany, Reprod. Biol. Endocrinol., 2011, 9, 101.

59. D. A. Correa Pinto and P. Monteiro Seraphim, Rev. Nutrição, 2012, 25, 313-319.

60. J. F. Lalanza, A. Caimari, J. M. del Bas, D. Torregrosa, I. Cigarroa, M. Pallàs, L. Capdevila, L. Arola and R. M. Escorihuela, PLoS One, 2014, 9, e85049.

61. C. J. Bailey, P. R. Flatt and N. S. Radley, Nutr. Res., 1985, 5, 1003-1010.

62. D. R. Bolster, L. S. Jefferson and S. R. Kimball, Proc. Nutr. Soc., 2004, 63, 351-356.

63. J. Grigsby, W. Bergen and R. Merkel, Growth, 1976, 40, 303-316.

64. R. C. May, J. L. Bailey, W. E. Mitch, T. Masud and B. K. England, Kidney Int., 1996, 49, 679-683.

65. D. H. Elwyn, F. E. Gump, M. Iles, C. L. Long and J. M. Kinney, Metabolism, 1978, 27, 325-331.

66. J. Van Raaij, C. M. Schonk, S. H. Vermaat-Miedema, M. Peek and J. Hautvast, Am. J. Clin. Nutr., 1991, 53, 612-619.

67. C. Moundras, C. Remesy and C. Demigne, Am. J. Physiol., 1993, 264, G1057-G1065.

68. B. K. Speake, R. Dils and R. J. Mayer, Biochem. J, 1976, 154, 359-370.

69. A. Husson, C. Brasse-Lagnel, A. Fairland, S. Renouf and A. Lavoinne, Eur. J. Biochem., 2003, 270, 1887-1899.

70. S. M. Morris, Annu. Rev. Nutr., 1992, 12, 81-101.

71. J. C. Marini, J. Nutr., 2012, 142, 572-580.

72. C. Vizioli de Castro Ghizoni, F. Rodrigues Silva Gasparin, A. Sueiti Maeda, F. Olinto Carreño, R. Polimeni Constantin, A. Bracht, E. L. Ishii Iwamoto and J. Constantin, Mol. Cell. Biochem., 2013, 373, 265-277.

73. W. Durante, F. K. Johnson and R. A. Johnson, Clin. Exp. Pharmacol. Physiol., 2007, 34, 906-911.

74. A. Ghasemi, S. Zahediasl and F. Azizi, Scand. J. Clin. Lab. Invest., 2012, 72, 523-530.

75. H. G. Windmueller and A. E. Spaeth, Am. J. Physiol., 1981, 241, E473-E480.

76. C. Breuillard, L. Cynober and C. Moinard, Amino Acids, 2015, 47, 685-691.

77. S. Grisolía, M. D. Miñana, E. Grau and V. Felipo, Adv. Exp. Med. Biol., 1994, 341, 1-12. 
78. A. J. Meijer, Trends Biochem. Sci., 1979, 4, 83-86.

79. C. H. C. Dejong, M. T. Kampman, N. E. P. Deutz and P. B. Soeters, J. Neurochem., 1992, 59, 1071-1079.

80. C. Rémésy, C. Moundras, C. Morand and C. Demigné, Am. J. Physiol., 1997, 272, G257-G264.

81. E. Cersosimo, P. Williams, R. Geer, T. Lairmore, F. Ghishan and N. N. Abumrad, Am. J. Physiol., 1989, 257, E514-E519.

82. L. Boon, W. J. C. Geerts, A. Jonker, W. H. Lamers and C. J. F. van Noorden, Histochem. Cell Biol., 1999, 111, 445-452.

83. L. R. Soria, J. Marrone, G. Calamita and R. A. Marinelli, Hepatology, 2013, 57, 2061-2071.

84. V. Rubio, G. Ramponi and S. Grisolía, Biochim. Biophys. Acta, 1981, 659, 150-160.

85. H. Nakagawa, S. Miura, H. Kimura and T. Kanatsuna, J. Biochem., 1969, 66, 549-564.

86. O. M. Wrong and A. Vince, Proc. Nutr. Soc., 1984, 43, 77-86.

87. R. da Silva, O. Levillain, J. T. Brosnan, S. Araneda and M. E. Brosnan, Can. J. Physiol. Pharmacol., 2013, 91, 362-368.

88. J. D. McGivan and J. B. Chappell, FEBS Lett., 1975, 52, 1-7.

89. K. K. Moss and J. D. McGivan, Biochem. J., 1975, 150, 275-283.

90. M. Szydlowska, G. Nagel-Starczynowska, I. Rybakowska, A. Swieca and K. Kaletha, Mol. Cell. Biochem., 2002, 241, 81-82.

91. A. J. Verhoeven, J. F. van Iwaarden, S. K. Joseph and A. J. Meijer, Eur. J. Biochem., 1983, 133, 241-244.

92. T. Yamada, J. Komoto, Y. Takata, H. Ogawa, H. C. Pitot and F. Takusagawa, Biochemistry, 2003, 42, 12854-12865.

93. R. K. Hampson, M. K. Taylor and M. S. Olson, J. Biol. Chem., 1984, 259, 1180-1185.

94. N. M. Anderson, F. I. Bennett and G. A. O. Alleyne, Biochim. Biophys. Acta, 1976, 437, 238-243.

95. J. M. Lowenstein, Int. J. Sports Med., 1990, 11, S37-S46.

96. Y. A. Kim, M. T. King, W. E. Teague, G. A. Rufo, R. L. Veech and J. V. Passoneau, Am. J. Physiol., 1992, 262, E344-E352.

97. P. Dzeja and A. Terzic, Int. J. Mol. Sci., 2009, 10, 1729-1772.

98. K. Tornheim, J. Theor. Biol., 1979, 79, 491-541.

99. G. Lutoslawska and M. Niedbalska, Medicina Sportiva, 2004, 8, 85-104.

100. K. Tornheim and J. M. Lowenstein, J. Biol. Chem., 1972, 247, 162-169.

101. H. A. Krebs, R. Hems, P. Lund, D. Halliday and W. W. C. Read, Biochem. J., 1978, 176, 733-737.

102. T. Yoshida and G. Kikuchi, Arch. Biochem. Biophys., 1970, 139, 380-392.

103. M. Alemany, Nutri. Res. Rev., 2012, 25, 18-28. 
104. M. Esteve, I. Rafecas, J. A. Fernández-López, X. Remesar and M. Alemany, Biochem. Mol. Biol. Int., 1993, 29, 1069-1081.

Figure 1 Gene expressions and enzyme activities of the urea cycle in the liver of male and female rats fed control or cafeteria diet for 30 days.

The data correspond to the mean \pm sem of 6 different animals, and are all expressed per gram of tissue protein (gP). Statistical analysis of the differences between groups was done using a two-way anova program and the variables "sex" and "diet".

Only significant $(P<0.05)$ values have been represented. Purple data, marked with a "S" correspond to the overall effect of "sex", and red data marked with a "D" correspond to the overall effect of "diet". $M C=$ male fed the control diet; $M K=$ male fed the cafeteria diet; $F C=$ female fed the control diet; FK = female fed the cafeteria diet.

Males: dashed columns; females: no-pattern columns.

Enzyme gene expressions: orange: control diet; yellow: cafeteria diet

Enzyme activities: blue: control diet; green: cafeteria diet

Figure 2 Gene expressions and enzyme activities of enzymes related to ammonia/ammonium metabolism in the liver of female and male rats fed control or cafeteria diet for 30 days.

The data correspond to the mean \pm sem of 6 different animals, and are expressed per gram of tissue protein (gP). Statistical analysis, abbreviations and colour conventions are the same described for Figure 1. 

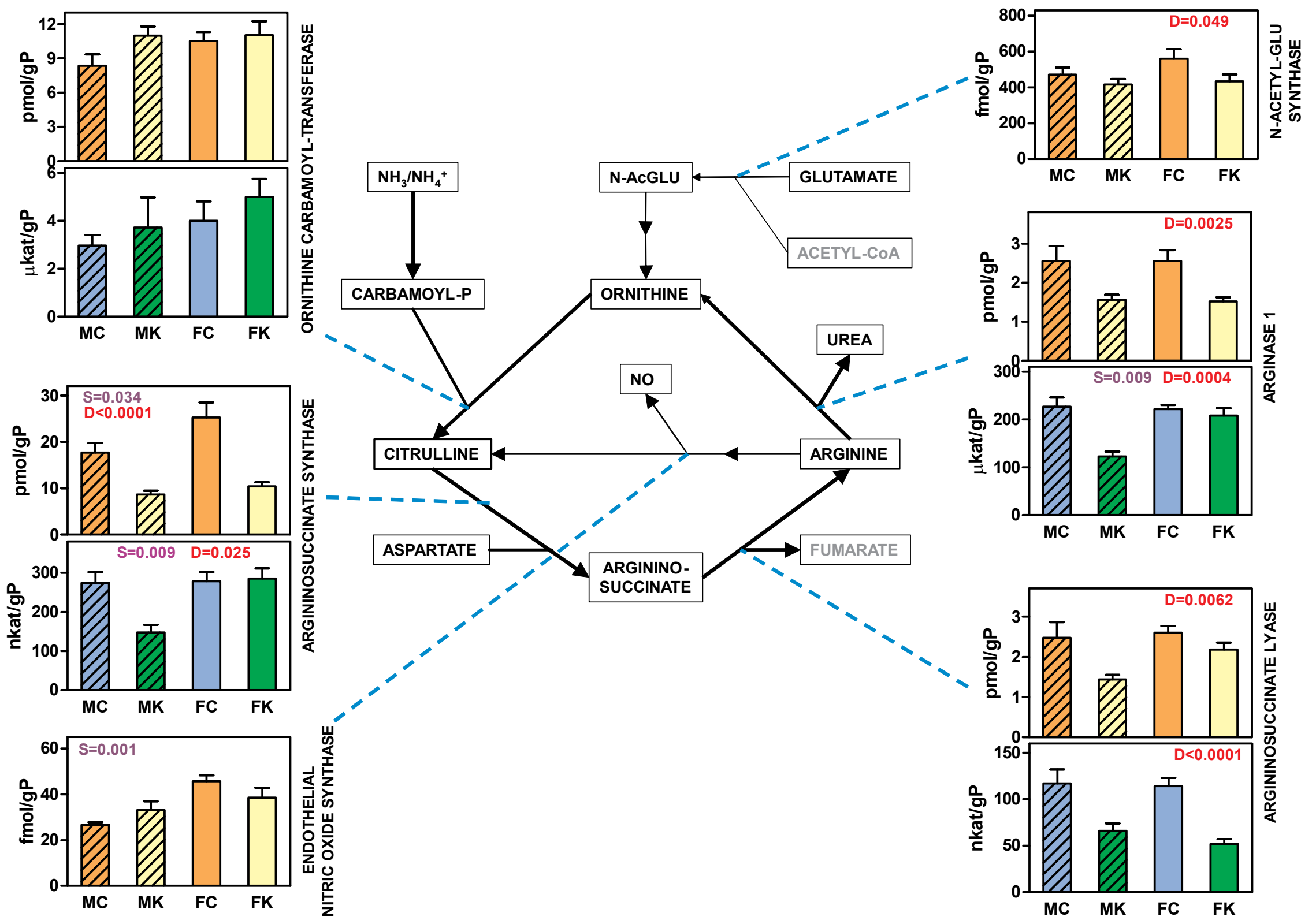

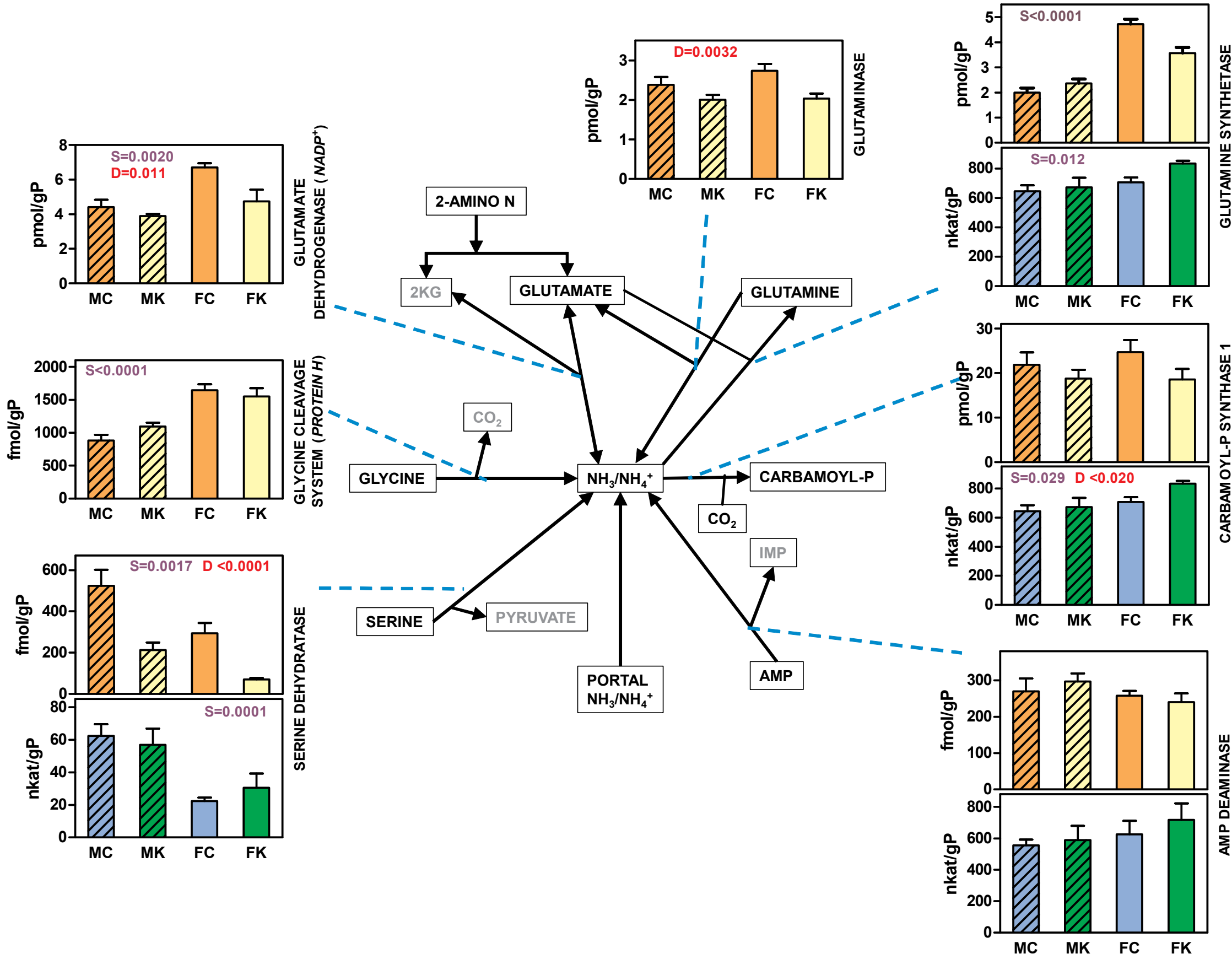


\section{Table 1}

Primer sequences used in the analysis of liver gene expressions

\begin{tabular}{|c|c|c|c|c|c|}
\hline protein & gene & EC number & & primer sequence & bp \\
\hline \multirow{2}{*}{$\begin{array}{l}\text { carbamoyl-phosphate } \\
\text { synthase [ammonia], } \\
\text { mitochondrial.type } 1\end{array}$} & \multirow{2}{*}{ Cps1 } & \multirow{2}{*}{ 6.3.4.16 } & $5^{\prime}>3^{\prime}$ & АСССАТСАТССССТСТGАСТ & \multirow{2}{*}{118} \\
\hline & & & $3^{\prime}>5$ & ACACGCCACCTCTCCAGTAG & \\
\hline \multirow{2}{*}{$\begin{array}{l}\text { ornithine carbamoyl- } \\
\text { transferase }\end{array}$} & \multirow{2}{*}{ Otc } & \multirow{2}{*}{ 2.1.3.3 } & $5^{\prime}>3^{\prime}$ & CTTGGGCGTGAATGAAAGTC & \multirow{2}{*}{126} \\
\hline & & & $3^{\prime}>5$ & ATTGGGATGGTTGCTTCCT & \\
\hline \multirow{2}{*}{$\begin{array}{l}\text { arginino-succinate synthase } \\
1\end{array}$} & \multirow{2}{*}{ Ass1 } & \multirow{2}{*}{ 6.3.4.5 } & $5^{\prime}>3^{\prime}$ & CAAAGATGGCACTACCCACA & \multirow{2}{*}{100} \\
\hline & & & $3^{\prime}>5$ & GTTCTCCACGATGTCAATGC & \\
\hline \multirow{2}{*}{ arginino-succinate lyase } & \multirow{2}{*}{ Asl } & \multirow{2}{*}{ 4.3.2.1 } & $5^{\prime}>3^{\prime}$ & CCGACCTTGCCTACTACCTG & \multirow{2}{*}{104} \\
\hline & & & $3^{\prime}>5$ & GAGAGCCACCCCTTTCATCT & \\
\hline \multirow{2}{*}{ arginase, liver (type 1) } & \multirow{2}{*}{$\operatorname{Arg} 1$} & \multirow{2}{*}{ 3.5.3.1 } & $5^{\prime}>3^{\prime}$ & GCAGAGACCCAGAAGAATGG & \multirow{2}{*}{126} \\
\hline & & & $3^{\prime}>5$ & GTGAGCATCCACCCAAATG & \\
\hline \multirow{2}{*}{$\mathrm{N}$-acetyl-glutamate synthase } & \multirow{2}{*}{ Nags } & \multirow{2}{*}{ 2.3.1.1 } & $5^{\prime}>3^{\prime}$ & GCAGCCCACCAAAATCAT & \multirow{2}{*}{82} \\
\hline & & & $3^{\prime}>5$ & CAGGTTCACATTGCTCAGGA & \\
\hline \multirow{2}{*}{$\begin{array}{l}\text { nitric oxide synthase } 3 \text {, } \\
\text { endothelial cell type }\end{array}$} & \multirow{2}{*}{ Nos3 } & \multirow{2}{*}{ 1.14.13.39 } & $5^{\prime}>3^{\prime}$ & CAAGTCCTCACCGCCTTTT & \multirow{2}{*}{138} \\
\hline & & & $3^{\prime}>5$ & GACATCACCGCAGACAAACA & \\
\hline \multirow{2}{*}{$\begin{array}{l}\text { glutamate-ammonia ligase } \\
\text { [glutamine synthetase] }\end{array}$} & \multirow{2}{*}{ Glul } & \multirow{2}{*}{ 6.3.1.2 } & $5^{\prime}>3^{\prime}$ & AACCCTCACGCCAGCATA & \multirow{2}{*}{148} \\
\hline & & & $3^{\prime}>5$ & CTGCGATGTTTTCCTCTCG & \\
\hline \multirow{2}{*}{$\begin{array}{l}\text { glutaminase kidney isoform, } \\
\text { mitochondrial }\end{array}$} & Glc & 3512 & $5^{\prime}>3^{\prime}$ & CCGAAGGTTTGCTCTGTCA & 63 \\
\hline & | & |0.1.2 & $3^{\prime}>5$ & AGGGCTGTTCTGGAGTCGTA & \\
\hline glutamate dehydrogenase 1 , & Glud1 & 1112 & $5^{\prime}>3^{\prime}$ & GGACAGAATATCGGGTGCAT & 122 \\
\hline mitochondrial & & & $3^{\prime}>5$ & TCAGGTCCAATCCCAGGTTA & \\
\hline glycine cleavage system $\mathrm{H}$ & $\mathrm{Gcch}$ & L & $5^{\prime}>3^{\prime}$ & AAGCACGAATGGGTAACAGC & 1116 \\
\hline protein, mitochondrial & | & & $3^{\prime}>5$ & TCCAAAGCACCAAACTCCTC & \\
\hline adenosine monophosphate & Amod2 & 3.5 .46 & $5^{\prime}>3^{\prime}$ & CGGCTTCTCTCACAAGGTG & 78 \\
\hline deaminase 2 & & & $3^{\prime}>5$ & CGGATGTCGTTACCCTCAG & \\
\hline peptidyl-prolyl-cis-trans & Pnia & - & $5^{\prime}>3^{\prime}$ & CTGAGCACTGGGGAGAAAGGA & 87 \\
\hline isomerase $A$ * & J & {$[-1$} & $3^{\prime}>5$ & GAAGTCACCACCCTGGACA & for \\
\hline
\end{tabular}

* housekeeping gene 


\section{Table 2}

Body and liver weight and composition of male and female rats fed control or cafeteria diets for 30 days

\begin{tabular}{|l|c|c|c|c|c|c|c|}
\hline \multirow{2}{*}{ parameter } & \multirow{2}{*}{ units } & \multicolumn{2}{|c|}{ male } & \multicolumn{2}{c|}{ female } & \multicolumn{2}{c|}{$\mathrm{P}$} \\
\cline { 3 - 8 } & & control & cafeteria & control & cafeteria & sex & diet \\
\hline body weight & $\mathrm{g}$ & $373 \pm 6$ & $420 \pm 20$ & $232 \pm 8$ & $267 \pm 16$ & $<0.0001$ & 0.0074 \\
\hline liver weight & $\mathrm{g}$ & $11.6 \pm 0.5$ & $13.8 \pm 1.1$ & $7.72 \pm 0.31$ & $8.36 \pm 0.50$ & $<0.0001$ & 0.0473 \\
\hline DNA & $\mathrm{mg} / \mathrm{g}$ & $2.07 \pm 0.17$ & $2.13 \pm 0.32$ & $1.83 \pm 0.22$ & $1.91 \pm 0.22$ & $\mathrm{NS}$ & $\mathrm{NS}$ \\
\hline RNA & $\mathrm{mg} / \mathrm{g}$ & $4.96 \pm 0.31$ & $5.21 \pm 0.18$ & $5.95 \pm 0.30$ & $5.75 \pm 0.15$ & 0.0065 & $\mathrm{NS}$ \\
\hline protein & $\mathrm{mg} / \mathrm{g}$ & $191 \pm 7$ & $185 \pm 5$ & $160 \pm 5$ & $157 \pm 9$ & 0.0003 & $\mathrm{NS}$ \\
\hline
\end{tabular}

The data correspond to the mean \pm sem of 6 different animals. Statistical significance of the differences between groups was established with a 2-way anova program. 


\section{Table 3}

Main plasma metabolites of male and female rats fed control or cafeteria diets for 30 days

\begin{tabular}{|l|c|c|c|c|c|c|c|}
\hline \multirow{2}{*}{$\begin{array}{l}\text { plasma } \\
\text { parameters (mM) }\end{array}$} & & \multicolumn{2}{|c|}{ male } & \multicolumn{2}{c|}{ female } & \multicolumn{2}{c|}{$\mathrm{P}$} \\
\cline { 3 - 7 } & & control & cafeteria & control & cafeteria & sex & diet \\
\hline glucose $^{1}$ & & $10.2 \pm 0.4$ & $10.8 \pm 0.4$ & $8.64 \pm 0.34$ & $11.5 \pm 0.3$ & NS & 0.0001 \\
\hline lactate & $3.10 \pm 0.29$ & $2.64 \pm 0.21$ & $3.78 \pm 0.24$ & $2.57 \pm 0.21$ & NS & 0.0023 \\
\hline cholesterol & $1.97 \pm 0.07$ & $2.28 \pm 0.21$ & $1.98 \pm 0.16$ & $2.07 \pm 0.19$ & NS & NS \\
\hline triacylglycerols & $1.50 \pm 0.06$ & $1.50 \pm 0.01$ & $1.69 \pm 0.06$ & $1.51 \pm 0.03$ & 0.0390 & NS \\
\hline urea & & $3.90 \pm 0.17$ & $3.82 \pm 0.20$ & $5.13 \pm 0.25$ & $3.78 \pm 0.20$ & 0.0094 & 0.0025 \\
\hline amino acids ${ }^{2}$ & & $3.34 \pm 0.08$ & $3.68 \pm 0.10$ & $3.96 \pm 0.18$ & $4.07 \pm 0.12$ & 0.0007 & NS \\
\hline
\end{tabular}

The data correspond to the mean \pm sem of 6 different animals. Statistical significance of the differences between groups was established with a two-way anova program.

1 The glucose values were higher than expected because of the necessary exposure of the animals to isoflurane anaesthesia during the process of killing and sampling.

2 These values do not include GIn, Asn, Trp and Cys. 